\title{
The cDNA Sequences of Equine Antioxidative Enzyme Genes Cu/Zn-SOD and Mn-SOD, and These Expressions in Equine Tissues
}

\author{
Nobushige ISHIDA, Yoshinari KATAYAMA, Fumio SATO, Telhisa HASEGAWA and Harutaka MUKOYAMA \\ Equine Research Institute, Japan Racing Association, 321-4 Tokami-cho, Utsunomiya, Tochigi 320-0856, Japan \\ (Received 6 July 1998/Accepted 2 November 1998)
}

ABSTRACT. The entire cDNA sequences were determined by reverse transcription-polymerase chain reaction (RT-PCR) and rapid amplification of cDNA ends (RACE) techniques for equine copper/zinc superoxide dismutase (Cu/Zn-SOD) and manganese superoxide dismutase (Mn-SOD) through the use of total RNA extracted from the testis of an adult Thoroughbred. The results revealed a protein coding region for equine $\mathrm{Cu} / \mathrm{Zn}$-SOD with bases totaling $465 \mathrm{bp}$, accompanied by an estimated 154 residues of amino acids. As for equine Mn-SOD, its coding region contained a total of $669 \mathrm{bp}$ and an estimated 222 residues of amino acids. Further, the expression of $\mathrm{Cu} / \mathrm{Zn}-$ SOD and Mn-SOD genes were confirmed in the equine tissues by RT-PCR and in situ hybridization. — KEY wORDS: equine, in situ hybridization, RT-PCR, SOD.

Organisms are inevitably exposed to active oxygen, which may denature their cell elements, proteins, lipids, and enzymes, leading to a variety of disorders, including inflammation [8], cancer [24], arteriosclerosis [25], myocardial injury [14], and aging [19]. To protect tissue from active oxygen, organisms are equipped with a multistage biological defense system. Cellular defense against superoxide anion is provided by a family of metalloenzymes, the superoxide dismutases, which catalyze the following reaction: $2 \mathrm{O}_{2}^{-}+2 \mathrm{H}^{+} \rightarrow \mathrm{H}_{2} \mathrm{O}_{2}+\mathrm{O}_{2}$ [7].

In mammals, the presence of the following three types of SOD has been confirmed: $\mathrm{Cu} / \mathrm{Zn}-\mathrm{SOD}$ found in the cytoplasm [17], Mn-SOD in the mitochondria [20], and ECSOD in serum [16]. The cDNA sequences of these enzymes in humans have already been determined [2, 6, 23]. In this study, to allow us to carry out our basic research and enable clinical application regarding the role of active oxygen and antioxidative enzymes in equine biological functions, the cDNA sequences of $\mathrm{Cu} / \mathrm{Zn}-\mathrm{SOD}$ and $\mathrm{Mn}-\mathrm{SOD}$ genes were first determined. Based on this data, the sequences of amino acids were then deduced. At the same time, the expressions of SOD genes in equine tissues were investigated by RTPCR and in situ hybridization.

Total RNA from the testis of an adult Thoroughbred was extracted by guanidinium/cesium chloride ultracentrifugation $[4,21]$, and used in cDNA synthesis with RNA PCR Kit (Takara, Kyoto) using random primer. For both $\mathrm{Cu} / \mathrm{Zn}$ SOD and Mn-SOD, RT-PCR was performed using primers designed by referring to highly conserved regions of cDNA sequences between humans $[2,23]$ and mice $[3,9]$. The PCR products were cloned to T-vector ( $\mathrm{pCR}^{\mathrm{TM}} \mathrm{II}$, Invitrogen, San Diego), and these cDNA sequences were determined by the dideoxy chain termination method [22]. Based on the cDNA sequences identified using the RT-PCR products, new PCR primers were designed. The entire cDNA sequences of equine $\mathrm{Cu} / \mathrm{Zn}-\mathrm{SOD}$ and $\mathrm{Mn}-\mathrm{SOD}$ genes were then determined by 5' RACE and 3' RACE methods [8] using a 5'/3' RACE Kit (Boehringer Mannheim, Tokyo). The expressions of SOD genes in equine tissues were confirmed by RT-PCR and in situ hybridization. Total RNAs for RT-PCR were extracted from the nine tissues; testis, adrenal gland, spleen, cerebrum, cerebellum, heart, thyroid gland, kidney, and liver. For in situ hybridization, the clones of equine $\mathrm{Cu} / \mathrm{Zn}$-SOD and Mn-SOD genes were digested with the restriction enzyme Spe I. In vitro transcription was conducted to produce RNA probes using a DIG-RNA Labeling Kit SP6/T7 (Boehringer Mannheim, Tokyo). In situ hybridization was conducted using a deparaffinated pieces of spleen tissue and these probes. Colorization was then performed using a DIG Nucleic Acid Detection Kit (Boehringer Mannheim, Tokyo) [15].

Figures 1 and 2 show the cDNA sequences of equine $\mathrm{Cu} /$ $\mathrm{Zn}$-SOD and Mn-SOD, together with deduced amino acid sequences. The 648-bp nucleotide sequence of $\mathrm{Cu} / \mathrm{Zn}$-SOD cDNA contains $79 \mathrm{bp}$ of the 5' flanking untranslated sequence, and a total of 465 of open reading frame coding 154 amino acids, 153 of which are considered to be mature peptides based on a report on humans [23]. The result was identical with the previously reported equine cDNA sequence [5]. The 971-bp nucleotide sequence of Mn-SOD cDNA, on the other hand, contains 69 bp of the 5' flanking untranslated sequence, and a total of 669 of open reading frame coding 222 amino acids. Comparing the deduced amino acid sequence with the known amino-terminal of mature human Mn-SOD, the first 24 amino acids of the primarily translated precursor may constitute the leader peptide for transport to the mitochondria [1].

Compared with other mammalian species, an $83 \%$ homology was found in the $\mathrm{Cu} / \mathrm{Zn}-\mathrm{SOD} \mathrm{cDNA}$ sequence for both equine genes with humans [23] and bovines [10], while an $81 \%$ homology was found with mice [3] and rats [11]. In amino acids, the homology was approximately $81 \%$ with humans [23], bovines [10], mice [3], and rats [11]. For Mn-SOD, on the other hand, an $89 \%$ homology was found in the cDNA sequence with humans [2], while an $84 \%$ homology was found with mice [9] and rats [12]. In amino acids, the homology was $92 \%$ with humans [2] and approximately $88 \%$ with mice [9] and rats [11]. These 


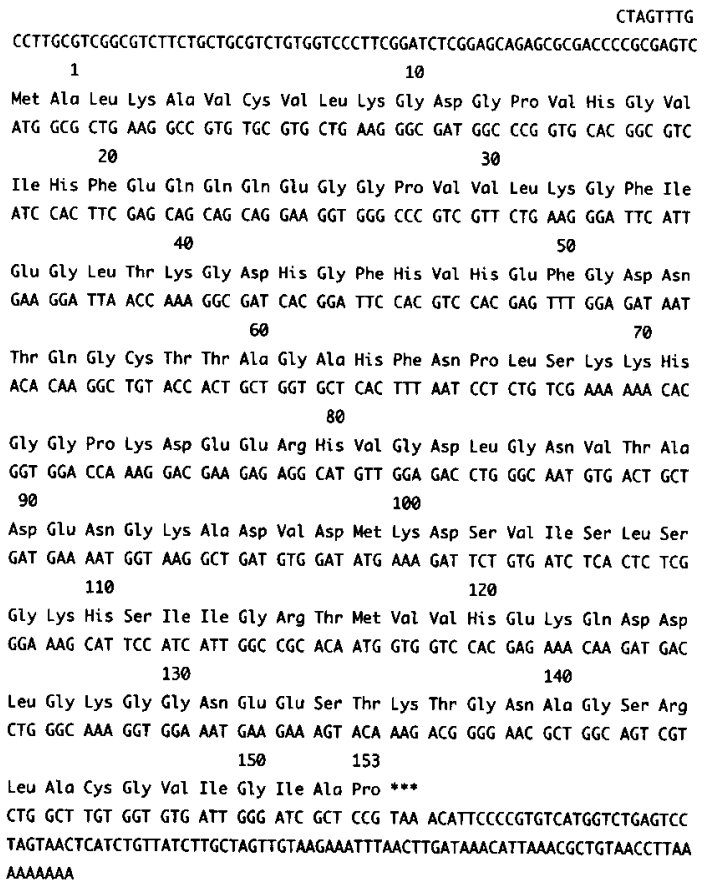

Fig. 1. Nucleotide sequence and deduced amino acid sequence of equine $\mathrm{Cu} / \mathrm{Zn}$ superoxide dismutase. The amino acid sequence corresponding to the entire mature protein is numbered $1-153$.

findings demonstrate that both genes are conserved highly among mammals.

The expressions of two SOD mRNAs were confirmed in all of the nine tissues by RT-PCR. From this result, it was suggested that two SOD mRNAs would be widely expressed in equine tissues. Using the probe RNA transcribed from SOD cDNA separated in our experiment, we performed in situ hybridization of the spleen tissue. The SOD distribution thus obtained revealed the notable presence of $\mathrm{Cu} / \mathrm{Zn}$-SOD in the germinal center of the spleen tissue. Mn-SOD expressed itself in this region, although only slightly. This confirms the effectiveness of the SOD cDNA clones as probes for SOD gene distribution in tissue, enabling us to employ it in examining the degree of SOD expression in damaged tissues.

It should be noted that the 190th of mature equine MnSOD peptides differs from that found in humans [13]. Since this region is regarded as the antigen recognition site in humans [13], we have already begun developing a quantitative analysis method for Mn-SOD in equine serum by the antipeptide antibody method, through the use of an antipeptide antibody obtained from the cDNA sequence identified in our study.

\section{REFERENCES}

1. Barra, D., Schinina, M. E., Simmaco, M., Bannister, J. V., Bannister, W. H., Rotilio, G. and Bossa, F. 1984. J. Biol. Chem. 259: 12595-12601.

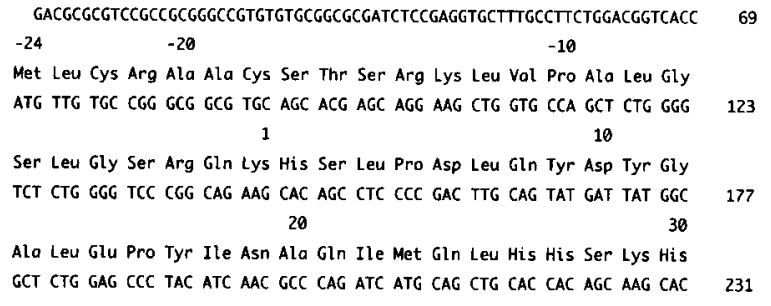

Ser Gly Trp Gly Trp Leu Gly Phe Asn Lys Asp Gln Gly Arg Leu Gln Ile Val TCG GGT TGG GGT TGG CTT GGT TTC AAT AAG GAC CAG GGA CGC CTC CAG ATT GTT

$$
140
$$

Ala Cys Pro asn Gln asp Pro leu gln Gly Thr Thr Gly leu Ile Pro Leu Leu GCC TGT CCT AAC CAG GAT CCC CTG CAG GGA ACA ACA GGT CTT ATT CCC CTG CTG 160 170 Gly Ile Asp Val Trp Glu His Ala Tyr Tyr Leu Gln Tyr Lys Asn val arg Pro GGG ATT GAC GTG TGG GAG CAC GCT TAT TAC CTT CAG TAT AAA AAT GTC AGG CCT 180 Asp Tyr Leu Lys Ala Ile Trp Asn Val Ile Asn Trp Glu Asn Val Ser Glu Arg GAT TAT CTG AAA GCC ATT TGG AAT GTS ATC AAC TGG GAG AAT GTA TCT GAG AGA 198 Tyr Met Ala Cys Lys Lys ***

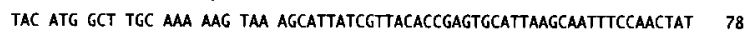
ITTTGTAGTAGCTCGAAGTACCACAGTATACCAGTAAGCTGCTCTAGGATAGCATITCTGATGTGGCTTA 852 ITCAGATATTTGATAAACGTAATGCTATGAATAATTICCTGIITTACAATTTIGTTATTGGGCAACTGTTT 923 GaAaATATTAaATGCTTTGTaTGaTtCGGTTAaAaAaAaAaAaAaAaA

Fig. 2. Nucleotide sequence and deduced amino acid sequence of equine manganese superoxide dismutase. The amino acid sequence corresponding to the entire mature protein is numbered 1-198.

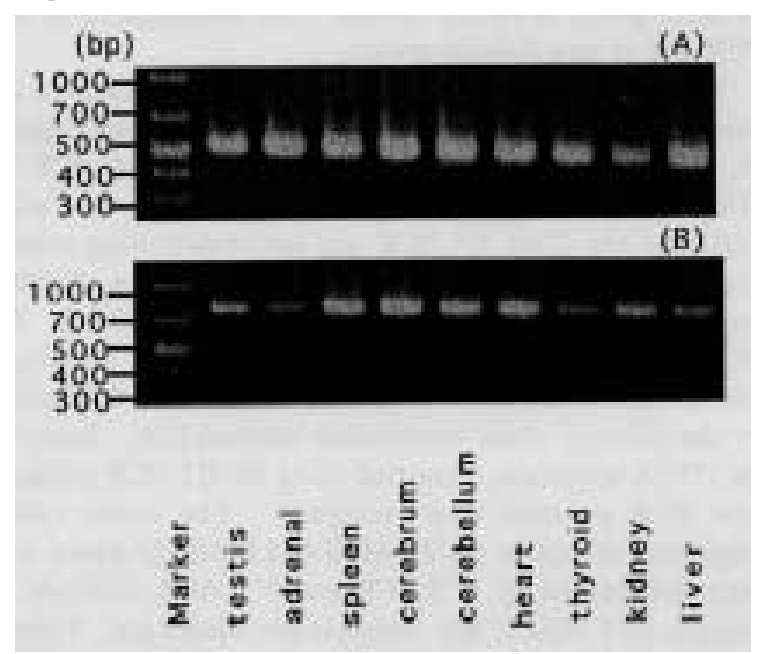

Fig. 3. RT-PCR in equine tissues. (A): Cu/Zn-SOD. (B): Mn-SOD. . 71 政 


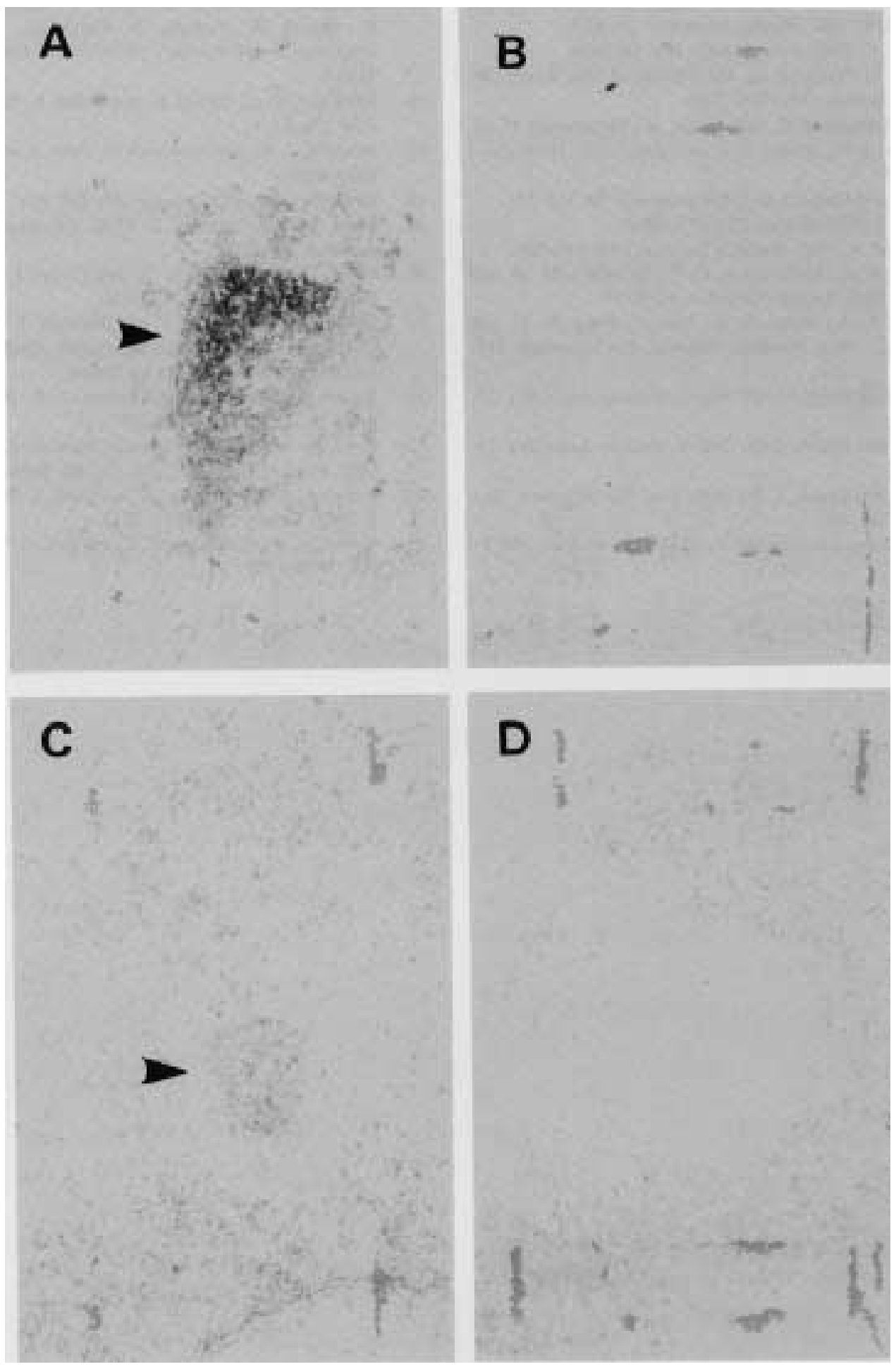

Fig. 4. ISH for the SODs mRNA in equine spleen. Magnification is X60. A: Positive hybridization signal (arrow head) with an anti-sense Cu/Zn-SOD RNA probe. B: Negative control with sense Cu/Zn-SOD RNA probe. C: Positive hybridization signal (arrow head) with an anti-sense Mn-SOD RNA probe. D: Negative control with sense Mn-SOD RNA probe. 
2. Beck, Y., Oren, R., Amit, B., Levanon, A., Gorecki, M. and Hartman, J. R. 1987. Nucleic Acids Res. 15: 9076.

3. Bewley, G. C. 1988. Nucleic Acids Res. 16: 2728.

4. Chirgwin, J., Przybyla, A., MacDonald, R. and Rutter, W. 1979. Biochemistry 18: 5294-5299.

5. de la Rua-Domenech, R., Wiedmann, M., Mohammed, H. O., Cummings, J. F., Divers, T. J. and Batt, C. A. 1996. Gene 178: 83-88.

6. Folz, R. J. and Crapo, J. D. 1994. Genomics 22: 162-171.

7. Fridovich, I. 1978. Science 201: 875-880.

8. Frohman, M. A. 1993. Methods Enzymol. 218: 340-356.

9. Hallewell, R. A., Mullenbach, G. T., Stempien, M. M. and Bell, G. I. 1986. Nucleic Acids Res. 23: 9539.

10. Hallewell, R. A., Imlay, K. C., Lee, P., Fong, N. M. and Gallegos, C. 1991. Biochem. Biophys. Res. Commun. 181: 474-480.

11. Ho, Y. S. and Crapo, J. D. 1987-a. Nucleic Acids Res. 15: 6746.

12. Ho, Y. S. and Crapo, J. D. 1987-b. Nucleic Acids Res. 15: 10070.

13. Ho, Y. S. and Crapo, J. D. 1988. Fed. Eur. Biochem. Soc. Lett. 229: 256-260.

14. Jolly, S. R. and Lucchesi, B. R. 1983. Am. Heart J. 106: 815 .
15. Kohric, K., Nomura, S., Kitamura, Y., Nagata, T., Yoshioka, K., Iguchi, M., Yamate, T., Umekawa, T., Suzuki, Y., Shinohara, H. and Kurita, T. 1993. J. Biol. Chem. 268: 15180 15184.

16. Marklund, S. L., Holme, E. and Heller, L. 1982. Clin. Chim. Acta 126: 41-51.

17. McCord, J. M. and Fridovich, I. 1969. J. Biol. Chem. 244: 6049-6055.

18. McCord, J. M. 1982. Science 185: 529-531.

19. Reiss, U. and Gershon, D. 1976. Biochem. Biophys. Res. Commun. 73: 255

20. Salin, M. L., Day, Jr. E. D. and Crapo, J. D. 1978. Arch. Biochem. Biophys. 187: 223-228.

21. Sambrook, J., Fritsch, E. F. and Maniatis, T. 1989. Molecular Cloning: A Laboratory Manual, 2nd ed., Cold Spring Harbour Laboratory Press, Cold Spring Harbor.

22. Sanger, F., Niklen, S. and Coulson, A. R. 1977. Proc. Natl. Acad. Sci. U.S.A. 74: 5463-5467.

23. Sherman, L., Dafni, N., Lieman-Hurwitz, J. and Groner, Y. 1983. Proc. Natl. Acad. Sci. U.S.A. 80: 5465-5469.

24. Weltman, S. A., Weiberg, A. B., Clark, E. P. and Stossel, T. P. 1985. Science 227: 1231-1233.

25. Wilson, R. B., Middleton, C. C. and Sun, G. Y. 1978. J. Nutr. 108: 1858-1967. 